\title{
Melatonin effects on ovarian follicular cells: a systematic review
}

\author{
Isabela Pasqualini Minguini ${ }^{1}$ \\ (D) Camila Maganhin Luquetti ${ }^{1}$ \\ (iD) Maria Cândida Pinheiro Baracat ${ }^{1}$ \\ (iD) Carla Cristina Maganhin ${ }^{1}$ \\ (iD) Camila de Oliveira Nunes ${ }^{1}$ \\ (iD) Ricardo Santos Simões ${ }^{1}$ \\ Dduardo Carvalho de Arruda Veiga' \\ (iD) José Cipolla-Neto ${ }^{2}$ \\ (iD) Edmund Chada Baracat ${ }^{1}$ \\ (iD) Jose Maria Soares Junior ${ }^{1}$
}

\begin{abstract}
1 Disciplina de Ginecologia do Departamento de Obstetrícia e Ginecologia, Hospital das Clínicas, Faculdade de Medicina da Universidade de São Paulo, São Paulo, SP, Brasil 2 Departamento de Fisiologia e Biofísica, Instituto de Ciências Biomédicas, Universidade de São Paulo, São Paulo, SP, Brasil
\end{abstract}

\section{SUMMARY}

Melatonin is known for its effects on both the sleep and reproductive system of mammals. The latter has melatonin receptors type 1 and 2, which act to regulate, among other things, cyclic AMP. Notwithstanding all the literature data, there is still no sound knowledge or a clear understanding of the hormone's action on the physiology of ovarian follicular cells.

OBJECTIVE: To review and evaluate studies about melatonin action on the ovarian granulosa/theca interna cells from the literature.

METHODS: The systematic review was carried out according to the PRISMA recommendations. The MEDLINE and Cochrane primary databases were consulted with the use of specific terms. There was no limitation on language or publication year.

RESULTS: Seven papers about melatonin action on granulosa cells were selected. The following can be attributed to the hormone's effects: a) progesterone increase in culture medium; b) increased estrogen production; c) antagonistic action on estrogen; $d$ ) improvement in cell quality resulting in improved embryo and higher pregnancy rates; e) improved cell proliferation via MAPK; f) reduction of free radicals. Nevertheless, there are contrarian papers reporting a reduction in progesterone production.

CONCLUSION: Melatonin interferes in sex steroid production, boosting progesterone output. Such action may help improve oocyte quality. KEYWORDS: Melatonin. Ovary. Granulosa cells.

\section{INTRODUCTION}

Melatonin is the main hormone produced by the pineal gland. Of all its functions, the most studied and with the best-structured data is the regulation of the circadian cycle and seasonal rhythms of the body $^{1,2}$. Only recently have other functions been studied more intensively. Some of these are control of glucose metabolism, modulation of humoral immune activity and vascular tone, and regulation of human reproductive function ${ }^{3-6}$.

Melatonin is an indolamine resulting from sero-

DATE OF SUBMISSION: 14-May-2019

DATE OF ACCEPTANCE: 17-May-2019

CORRESPONDING AUTHOR: Eduardo Carvalho de Arruda Veiga

Rua Dr. Enéas de Carvalho Aguiar, 255, 10ํAndar - sala 10.166 - Cerqueira César - São Paulo, SP, Brasil - CEP 05403-900 - Tel: $3069-6647$ Email: eduveiga56@gmail.com 
tonin acetylation and methylation ${ }^{7}$. As a powerful antioxidant $^{6,8,9}$, more so than glutathione ${ }^{7}$, it has an important role in controlling free radicals. Using endocrine, paracrine, and autocrine signaling, mediated or not by membrane receptors like MT1 and MT2 ${ }^{1,10,11}$, melatonin plays a still unclear role in human ovarian physiology ${ }^{7,10}$. The human follicular fluid contains high melatonin concentrations - higher than those in serum concentrations - mainly in preovulatory follicles ${ }^{2}$. There are studies correlating melatonin concentrations in follicular fluid with those of progesterone, estradiol, and even oxytocin ${ }^{12-14}$. Thus, the scientific investigation into melatonin's role and action mechanisms in the ovary may open up new horizons for the treatment of several diseases of the female reproductive system, including endometriosis, ovarian neoplasms, and polycystic ovary syndrome $e^{6,15}$. In short, the key question to address, which has been the source of much discussion, is melatonin's influence on ovarian follicle cells ${ }^{7}$.

This systematic review aimed at gathering and analyzing research work about melatonin effects on human ovarian follicle cells published in the literature up to the present. The ultimate objective was to consolidate knowledge in this field.

\section{METHODS}

The systematic review followed the procedures established by PRISMA ${ }^{16}$. The search strategy and the databases that were consulted are shown in Fig- ure 1 . An option was made not to exclude papers with respect to publication time to allow an analysis of the relevance of the topic throughout the decades. The search, thereby, yielded articles ranging from 1986 to 2017. The PICO was defined as follows: P (Patients) patients with infertility; I (intervention) melatonin in the granulosa cells; C (control) women with normal menstrual cycle and a male factor; and o (outcome) melatonin's effect.

The initial selection was carried out based on the title; studies unavailable in English, Portuguese, Spanish, Italian, or French or those not addressing the central issue of this review were excluded. Only original papers reporting on research conducted with humans and reviews on the subject were included. Work using animal models was excluded. This phase was followed by the reading of abstracts and the screening out of articles unrelated to the topic.

Study selection was carried out by two researchers (I.P.M. and R.S.S.) who worked independently, following the eligibility criteria. When there was disagreement, a third reviewer was consulted (J.M.S.J.).

The phase above yielded 15 studies to be read entirely (Fig. 2). In addition, reviews, as well as references, were examined to enhance our research (evaluation of the literature in the "gray area").

A table was used to organize the following data from the articles: title, authors, year, study design, number of participants $(\mathrm{N})$, general objectives, methods, results, and study limitations.

TABLE 1. CHARACTERISTICS OF THE STUDIES INCLUDED IN THE SYSTEMATIC REVIEW

\begin{tabular}{l|l|l|l|l}
$\begin{array}{l}\text { Authors and year of } \\
\text { publication }\end{array}$ & Country & Sample & Kind of study & Outcome \\
\hline Kim et al.3, 2013 & South Korea & $\begin{array}{l}\text { Human and oocyte } \\
\text { granulosa cells }\end{array}$ & Cell culture & $\begin{array}{l}\text { Improvement in embryo } \\
\text { implantation }\end{array}$ \\
\hline Taketani et al.9, 2011 & Japan & Granulosa cells & Cell culture & Decrease of free radicals \\
\hline Nakamura et al.7, 2003 & Japan & $\begin{array}{l}\text { Human granulocyte cells } \\
\text { and follicles }\end{array}$ & $\begin{array}{l}\text { Cellular and follicular } \\
\text { culture }\end{array}$ & $\begin{array}{l}\text { Increased melatonin } \\
\text { is accompanied by } \\
\text { increased progesterone }\end{array}$ \\
\hline Woo et al.10, 2001 & Canada & Human granulosa cells & Cell culture & $\begin{array}{l}\text { Activation of MAPK } \\
\text { (mitosis) and discrete } \\
\text { progesterone increase }\end{array}$ \\
\hline Bódis et al.17, 2001 & Hungary & Human granulosa cells & Cell culture & $\begin{array}{l}\text { Estradiol stimulation and } \\
\text { progesterone reduction }\end{array}$ \\
\hline Niles et al.11, 1999 & Canada & Human granulosa cells & Without cell culture & $\begin{array}{l}\text { Presence of the melatonin } \\
\text { receptor }\end{array}$ \\
\hline Yie et al.18, 1995 & Canada & Human granulosa cells & Cell culture & $\begin{array}{l}\text { Presence of the melatonin } \\
\text { receptor } \\
\text { Increased production of } \\
\text { progesterone }\end{array}$ \\
\hline
\end{tabular}




\section{RESULTS}

The database search produced a total of 116 articles. Selection narrowed this number down to 7 studies about melatonin action on the granulosa cells (Fig. 2). The data are summarized in Table 1. Most papers were from Canada. Only one study did not use cells from a cell culture; measurements were made directly on the cells after collection. The patients were in the 22 to 35 age range. The studies had a transverse design.

What follows can be attributed to melatonin action on the granulosa cells: a) progesterone increase in culture medium; b) stepped up estrogen production; c) antagonistic action on estrogen; d) improvement in cell quality resulting in improved embryo and higher pregnancy rates; e) improved cell proliferation via MAPK; and $f$ ) reduction in free radicals. Nevertheless, there are contrarian papers reporting a reduction in progesterone production ${ }^{8}$.

The studies imposed limitations on this review, given the diverse stimulation protocols for the women in the assisted fertility programs and different methods for evaluating melatonin. The varied intracellular signaling pathways further compounded the complexities of the review.

\section{DISCUSSION}

Ovulation is a process involving adequate interaction between follicular cells and substances participating in the inflammatory process, such as prostaglandins and cytokines, as well as the action of proteolytic enzymes and vasoactive substances ${ }^{9}$. Regulating this process is crucial for successful egg release and oocyte quality. It is also known that the macrophages, neutrophils, and vascular endothelium itself in the follicles produce reactive oxygen species (ROS) as well as reactive nitrogen species (RNS) during the ovulation process. The ROS participate in follicle maturation and rupture for oocyte release. However, excessive production of such substances is potentially harmful to the granulosa cells as it may hinder ovulation and corpus luteum formation and even impair embryo quality due to changes in DNA. It may compromise the lipid peroxidation of the oocyte membrane as well ${ }^{5,8}$. Therefore, melatonin's antioxidant action may aid in the process ${ }^{5,8,9}$. Other melatonin roles reported in the studies were those as hormone receptor regulator and as an aid in adequate follicle growth.

Taketani et al. ${ }^{9}$ evaluated ROS melatonin effects in a culture of follicle cells from healthy women undergoing in vitro fertilization (IVF). Melatonin regulated progesterone production in the cells and reduced ROS. These mechanisms may explain the data showing enhanced implant rate under melatonin treatment ${ }^{17,19}$.

Melatonin receptors are located in the ovarian granulosa cells $s^{1,710}$. Perhaps the reduction in ROS is related to melatonin's intracellular signaling ${ }^{7}$. However, there is evidence that melatonin has other properties, which are independent of its receptors ${ }^{11,18}$. Nonetheless, during the ovulation process, the melatonin levels in the follicular fluid increase threefold over those in blood circulation ${ }^{20}$. The aim is possibly to regulate follicle growth and decrease reactive oxygen species, as well as to influence sex steroid production and action in the follicle microenvironment.

During follicle growth, melatonin's Gi-mediated intracellular signaling pathway, which influences the second messengers (AMPc and GMPc), and its Gs-mediated pathway, which affects PKC activity ${ }^{1}$, possibly stimulate granulosa cell proliferation through MAPK activation. This potential mechanism was confirmed in vitro with melatonin treatment and ELK-1 phosphorylation, which is a dose-and-time-dependent action. During ovulation with a high melatonin concentration, the reverse occurs, i.e., a reduction in cell proliferation and in MAPK activation ${ }^{10}$. This is a property that may be important for egg release and enables cell apoptosis, acts as a brake on follicle growth, and reduces ROS ${ }^{9}$.

Melatonin's influence on steroidogenesis seems to be dose-dependent, involving both central mechanisms and the ovarian microenvironment. Between $10 \mathrm{pM}$ and 100nM of melatonin, there is an increase

FIGURE 1. DATABASES USED AND SEARCH STRATEGIES.

Medline: ("Ovarian Function Tests" OR "Ovarian Reserve" OR "Ovarian Follicle" OR "Theca Cells" OR "Follicular Fluid" OR "Ovary" OR "Ovarian Tissue" OR "Granulosa Cells") AND ("Melatonin" OR "Melatonin Receptors")

Cochrane: Follicular Cells AND melatonin

Embase: 'ovarian follicles/exp AND (melatonin/exp OR ovary/exp). 
FIGURE 2. ALGORITHM OF THE SELECTION OF THE STUDIES

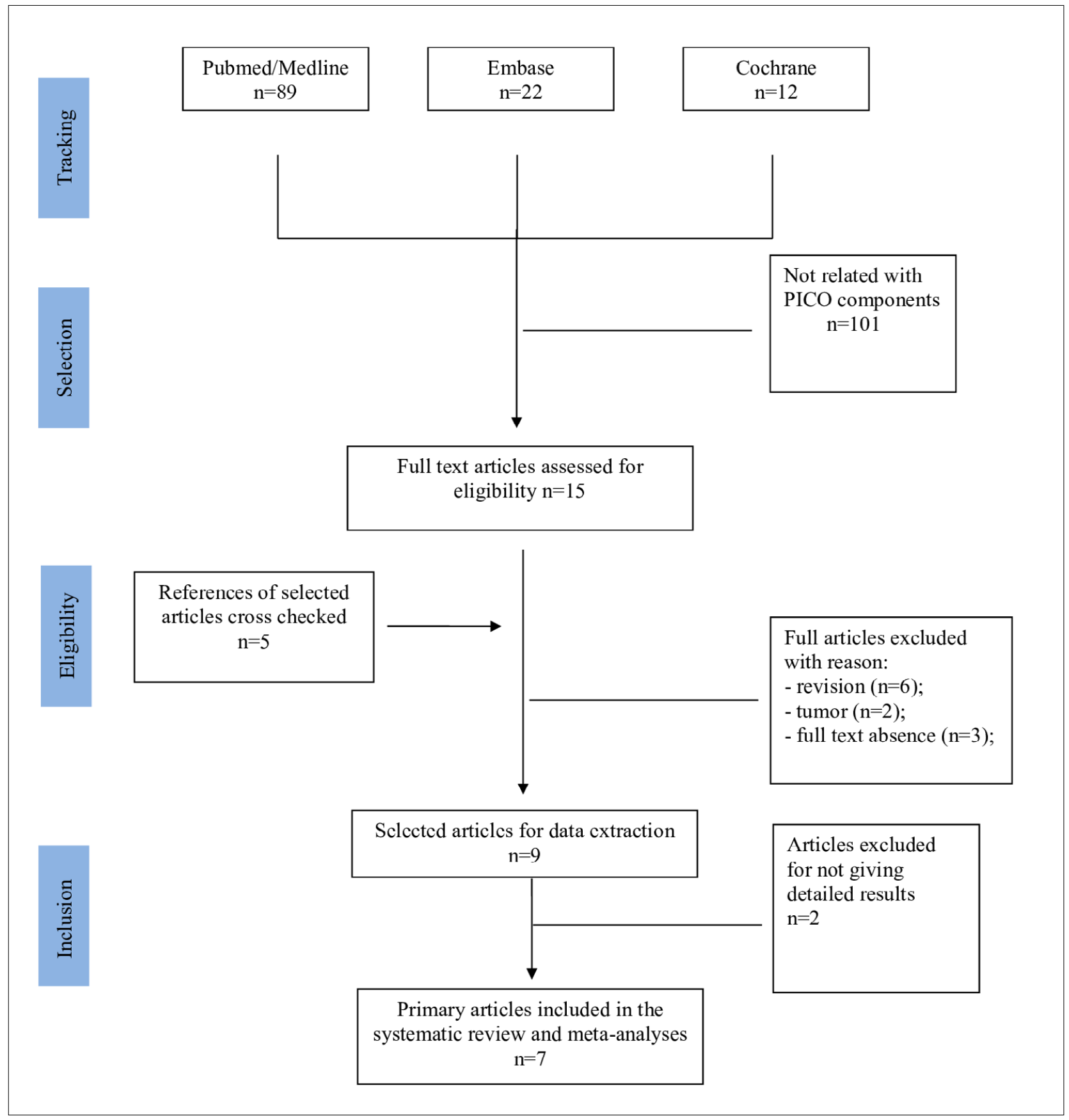

in the luteinizing hormone $(\mathrm{LH})$ receptor messenger RNA with no concomitant changes in the follicle-stimulating hormone (FSH) receptor gene expression, and there is also a reduction superior to $45 \%$ in gonadotropin-releasing hormone (GnRH) receptor messenger $\mathrm{RNA}^{3,9,10,16}$. This action has immediate repercussions in steroid production"1. With respect to melatonin's direct action on the granulosa cells, it appears that melatonin is involved in the luteinization of the cells and in a rise in progesterone production ${ }^{21}$. This would be an important effect with a bearing on endometrial preparation and embryo receptivity. On the other hand, there is a study showing a reverse action ${ }^{10}$. A tentative explanation is that the heterogeneity of the stimulation protocols used in the studies influenced the number of gonadotropin receptors. Another point is the amount of melatonin on the granulosa cells and their time of exposure to it, which may have impacted steroidogenesis ${ }^{10}$. In general, via its receptor, melatonin can negatively influence estrogen production ${ }^{\mathbf{1 6}}$. This could be important for the pituitary release of LH (peak) as well as for egg release ${ }^{22}$.

Our study was hindered by a few limitations capable of affecting our results. For example, the adop- 
tion of different stimulation protocols in the ovarian stimulation programs may have influenced both gonadotropin action and steroidogenesis. The time span between the beginning of cell culture and the melatonin treatment varied among the studies. This fact may have biased the analyses, given that gonadotropin receptors may be more abundant in the longer-span cultures and less so in those with a shorter time span. Moreover, melatonin action is known to depend on the interaction with gonadotropins, especially LH. A further limitation was the use of different protocols to evaluate melatonin.

Finally, melatonin seems to interfere in sex steroid production (progesterone increase and estrogen decrease) and in the reduction of free radicals in follicle cells after ovarian stimulation protocols by assisted reproduction techniques. However, it is necessary to confirm this melatonin action on the quality of both the granulosa cells and the oocytes.

\section{CONCLUSIONS}

We conclude that melatonin has actions in the production of sex hormones, in the improvement of antioxidant parameters, in the increase of cellular proliferation and in the oocyte quality. However, further studies are necessary to verify the actions of melatonin.

This study was supported by FAPESP, CNPq, and CAPES (Brasil-Br)

Statement: The authors do not have any conflict of interest

Acknowledgments: This study was supported by grants from CAPES, FAPESP, and CNPq.

\section{Competing interests}

The authors declare that they have no competing interests

\section{Author Contributions}

IPM - made substantial contributions to the concept, design of the study and definition of intellectual content; was involved in literature search, data analysis, statistical analysis, manuscript preparation, manuscript writing; drafting the article or revising it critically for important intellectual content; and final approval of the version to be published.

CML - made substantial contributions to the concept, design of the study and definition of intellectual content; was involved in literature search, data anal- ysis, statistical analysis, manuscript preparation, manuscript writing; drafting the article or revising it critically for important intellectual content; and final approval of the version to be published.

MCPB - made substantial contributions to the concept, design of the study and definition of intellectual content; was involved in literature search, data analysis, statistical analysis and final approval of the version to be published.

CCM - made substantial contributions to the concept, design of the study and definition of intellectual content; was involved in literature search, data analysis, statistical analysis and final approval of the version to be published. -

CON - made substantial contributions to the concept, design of the study and definition of intellectual content; was involved in literature search, data analysis, statistical analysis and final approval of the version to be published. -

RSS - made substantial contributions to the concept, design of the study and definition of intellectual content; was involved in literature search, data analysis, statistical analysis and final approval of the version to be published. -

ECAV - made substantial contributions to the concept, design of the study and definition of intellectual content; was involved in literature search, data analysis, statistical analysis and final approval of the version to be published

JCP - made substantial contributions to the concept, design of the study and definition of intellectual content; was involved in literature search, data analysis, statistical analysis, manuscript preparation, manuscript writing; drafting the article or revising it critically for important intellectual content; and final approval of the version to be published.

ECB - made substantial contributions to the concept, design of the study and definition of intellectual content; was involved in literature search, data analysis, statistical analysis, manuscript preparation, manuscript writing; drafting the article or revising it critically for important intellectual content; and final approval of the version to be published.

JMSJ - made substantial contributions to the concept, design of the study and definition of intellectual content; was involved in literature search, data analysis, statistical analysis, manuscript preparation, manuscript writing; drafting the article or revising it critically for important intellectual content; and final approval of the version to be published. 


\section{RESUMO}

A melatonina é conhecida por seus efeitos no sono e no sistema reprodutivo dos mamíferos. Este último tem receptores de melatonina tipos 1 e 2, que atuam para regular, entre outras coisas, o AMP cíclico. Apesar de todos os dados da literatura, ainda não há um conhecimento sólido ou uma compreensão clara da ação do hormônio na fisiologia das células foliculares ovarianas.

OBJETIVO: Revisar e avaliar estudos da ação da melatonina na literatura sobre as células internas da granulosa/teca ovariana.

MÉTODOS: A revisão sistemática foi realizada de acordo com as recomendações do Prisma. As bases de dados primárias Medline e Cochrane foram consultadas com o uso de termos específicos. Não houve bar na língua ou ano de publicação.

RESULTADOS: Sete artigos sobre a ação da melatonina nas células da granulosa foram selecionados. O que se segue pode ser atribuído aos efeitos do hormônio: a) aumento de progesterona no meio de cultura; b) aumento da produção de estrogênio; c) ação antagônica no estrogênio; d) melhoria na qualidade celular, resultando em melhor embrião e maiores taxas de gravidez; e) melhor proliferação celular via MAPK; f) redução de radicais livres. No entanto, existem artigos controversos relatando redução na produção de progesterona.

CONCLUSÃO: A melatonina interfere na produção de esteroides sexuais, aumentando a produção de progesterona. Tal ação pode ajudar a melhorar a qualidade do oócito.

PALAVRAS-ChaVE: Melatonina. Ovário. Células da granulosa.

\section{REFERENCES}

1. Ekmekcioglu C. Melatonin receptors in humans: biological role and clinical relevance. Biomed Pharmacother. 2006;60(3):97-108.

2. Brzezinski $A$, Seibel MM, Lynch HI, Deng MH, Wurtman RJ. Melatonin in human preovulatory follicular fluid. J Clin Endocrinol Metab. 1987;64(4):865-7.

3. Kim MK, Park EA, Kim HJ, Choi WY, Lee WS, Cha KY, et al. Does supplementation of in-vitro culture medium with melatonin improve IVF outcome in PCOS? Reprod Biomed Online. 2013;26(1):22-9.

4. Reiter RJ, Tamura H, Tan DX, Xu XY. Melatonin and the circadian system: contributions to successful female reproduction. Fertil Steril. 2014;102(2):321-8

5. Tamura H, Takasaki A, Taketani T, Tanabe M, Kizuka F, Lee L, et al. Melatonin as a free radical scavenger in the ovarian follicle. Endocr J. 2013;60(1):1-13.

6. Tamura H, Nakamura Y, Korkmaz A, Manchester LC, Tan DX, Sugino M, et al. Melatonin and the ovary: physiological and pathophysiological implications. Fertil Steril. 2009;92(1):328-43.

7. Nakamura Y, Tamura H, Takayama H, Kato H. Increased endogenous level of melatonin in preovulatory human follicles does not directly influence progesterone production. Fertil Steril. 2003;80(4):1012-6.

8. Cruz MH, Leal CL, Cruz JF, Tan DX, Reiter RJ. Essential actions of melatonin in protecting the ovary from oxidative damage. Theriogenology. 2014;82(7):925-32.

9. Taketani T, Tamura H, Takasaki A, Lee L, Kizuka F, Tamura I, et al. Protective role of melatonin in progesterone production by human luteal cells. | Pineal Res. 2011;51(2):207-13.

10. Woo MM, Tai C), Kang SK, Nathwani PS, Pan SF, Leung PC. Direct action of melatonin in human granulosa-luteal cells. J Clin Endocrinol Metab. 2001;86(10):4789-97.

11. Niles LP, Wang J, Shen L, Loob DK, Younglai EV. Melatonin receptor mRNA expression in human granulosa cells. Mol Cell Endocrinol. 1999;156(1-2):107-10.

12. Schaeffer HJ, Sirotkin AV. Melatonin and serotonin regulate the release of insulin-like growth factor-I, oxytocin and progesterone by cultured human granulosa cells. Exp Clin Endocrinol Diabetes. 1997;105(2):109-12.

13. Yie SM, Brown GM, Liu GY, Collins |A, Daya S, Hughes EG, et al. Melatonin and steroids in human pre-ovulatory follicular fluid: seasonal variations and granulosa cell steroid production. Hum Reprod. 1995;10(1):50-5.

14. Webley GE, Luck MR, Hearn JP. Stimulation of progesterone secretion by cultured human granulosa cells with melatonin and catecholamines. J Reprod Fertil. 1988;84(2):669-77.

15. Agarwal A, Gupta S, Sikka S. The role of free radicals and antioxidants in reproduction. Curr Opin Obstet Gynecol. 2006;18(3):325-32.

16. Moher D, Liberati A, Tetzlaff], Altman DG; PRISMA Group. Preferred reporting items for systematic reviews and meta-analysis: the PRISMA statement. PLoS Med. 2009;6(7):e1000097.

17 Bódis |, Koppán M, Kornya L, Tinneberg HR, Török A. Influence of melatonin on basal and gonadotropin-stimulated progesterone and estradiol secretion of cultured human granulosa cells and in the superfused granulosa cell system. Gynecol Obstet Invest. 2001;52(3):198-202.

18. Yie SM, Niles LP, Younglai EV. Melatonin receptors on human granulosa cell membranes. J Clin Endocrinol Metab. 1995;80(5):1747-9.

19. Carlomagno G, Minini M, Tilotta M, Unfer V. From implantation to birth: insight into molecular melatonin functions. Int J Mol Sci. 2018;19(9):2802-18.

20. Andersen CY, Humaidan P, Ejdrup HB, Bungum L, Grøndahl ML, Westergaard LG. Hormonal characteristics of follicular fluid from women receiving either $\mathrm{GnRH}$ agonist or hCG for ovulation induction. Hum Reprod. 2006;21(8):2126-30.

21. Tanabe M, Tamura H, Taketani T, Okada M, Lee L, Tamura I, et al. Melatonin protects the integrity of granulosa cells by reducing oxidative stress in nuclei, mitochondria and plasma membranes in mice. J Reprod Dev. 2015;61(1):35-41.

22. Maitra SK, Hasan KN. The role of melatonin as a hormone and an antioxidant in the control of fish reproduction. Front Endocrinol (Lausanne). 2016;7:38. 